\title{
Genetic basis of the resistance to Strongyloides venezuelensis (Nematoda, Rhabdiasidae) infection in mice (Mus musculus)
}

\author{
Nelson Mendes Marra, Alessandro F.T. Amarante and Mônica R.V. Amarante \\ Departamento de Parasitologia, Instituto de Biociências, Universidade Estadual Paulista, Botucatu, \\ SP, Brazil.
}

\begin{abstract}
We investigated the resistance to Strongyloides venezuelensis primary infection of mice strains $\mathrm{NIH}$ (resistant) and C57BL/6 (susceptible) and the F1 and F2 offspring of crosses between these strains. The mice were infected with 2000 larvae and seven days later were sacrificed for parasite recovery and counting. There was no statistically significant $(p>0.05)$ sex effect on resistance. The F1 mice showed an intermediate mean number of parasites as compared to the parental NIH and C57BL6 strains. Out of $400 \mathrm{~F} 2$ mice, the 10\% most resistant mice were infected with 21 to 97 parasites, while the $10 \%$ most susceptible mice were infected with 1027 to 1433 parasites. We also found that F2 mice with black fur $(n=72)$, the same color as the C57BL/6 susceptible parental strain, were more susceptible than white $(n=104)$ or gray furred $(n=224)$ mice. It is conceivable that some genes determining coat color are located on the same chromosome as where genes controlling helminth resistance.
\end{abstract}

Key words: mice, Strongyloides venezuelensis, resistance, genetics.

Received: September 20, 2005; Accepted: July 10, 2006.

\section{Introduction}

In animal production, parasitic infections are an important factor which increase production costs, principally due to reduced yield and, in the case of helminth infections, the cost of anthelmintics. Helminth control in domestic animals is mainly based on treatment with anthelmintics, but this practice is becoming less effective due to the development of resistant parasite populations (Amarante et al., 1992; Echevarria et al., 1996; Waller, 1997).

Genome mapping techniques have been employed to identify molecular markers associated with genes for economically important traits or disease resistance, allowing the selection of more productive or resistant animals (Gogolin-Ewens et al., 1990). It is assumed that many yield-related traits in livestock and plants are controlled by a large number of genes from different loci called quantitative trait loci (QTL) (Georges, 2001). Therefore, a QTL may comprise many genes that account for host protection against pathogens (Valladares-Hernandez et al., 2004).

Mice (Mus musculus) are one of the main experimental models used in genetic mapping for the identification of

Send correspondence to Nelson Mendes Marra. Departamento de Parasitologia, Instituto de Biociências, Universidade Estadual Paulista, Caixa Postal 510, 18618-000 Botucatu, SP, Brazil. E-mail: marra52@hotmail.com. molecular markers associated with resistance to parasitic infections. Complex resistance mechanisms can be easily analyzed through controlled crosses between resistant and susceptible inbred strains of mice (Marshall et al., 1992; Darvasi, 1998). Mice have been used as experimental model because they are simple, fast and relatively cheap to raise and maintain in large numbers.

Molecular markers associated with resistance to nematode infection in mice may contribute to mapping orthologues in ruminants because of the high chromosomal and gene similarity observed in mammals from comparative genome mapping data of ruminants, mice and humans (Lyons et al., 1997; Modi et al., 1998; O’Brien et al., 1999; Amarante et al., 2000; Band et al., 2000; Iannuzzi et al., 2001; Amarante and Amarante, 2003). It is important to remember that comparative maps have also been built to identify QTLs and eligible genes acting as a source of molecular markers for marker assisted selection (Rexroad et al., 2001).

Studies on acquired resistance to gastrointestinal nematodes in mice using crosses between resistant and susceptible mice strains have shown that a large number of QTLs are involved in the immunological response of the hosts (Behnke et al., 2003; Iraqi et al., 2003; Menge et al., 2003). However, there is also innate resistance against parasitic infections, which is observed in some strains of mice 
after primary infection by helminths. This is the case of the NIH strain of mice that proved to be highly resistant to primary infection by Strongyloides venezuelensis (Nematoda: Rhabdiasidae) in comparison with the C57BL/6 mouse strain (Amarante and Oliveira-Sequeira, 2002). Rattus norvegicus is the natural host of S. venezuelensis (Nakai and Amarante, 2001) but this nematode also easily infects mice, which are thus extensively used as models in studies of the immunology of nematode diseases (Negrão-Corrêa et al., 2004; Sasaki et al., 2005).

The broad aim of the research described in this paper is to elucidate the complex interaction between Strongyloides infections and the host response. We report on a study which compared the $S$. venezuelensis primary infection response of $\mathrm{NIH}$ (resistant) and C57BL/6 (susceptible) mice strains and the F1 and F2 generation of crosses between these strains. The association between sex, coat color and resistance to $S$. venezuelensis infection was also evaluated.

\section{Material and Methods}

\section{Animals and artificial infection}

We obtained Mus musculus mice strains NIH from Instituto de Ciências Biológicas, Universidade Federal de Minas Gerais (UFMG), Belo Horizonte, Minas Gerais, Brazil and C57BL/6 from the Vivarium Center (Centro de Bioterismo), Universidade Estadual de Campinas (Unicamp), Campinas, SP, Brazil. Male and female mice and their descendants were kept at the Laboratory of Animal Experimentation, Departamento de Parasitologia, Instituto de Biociências, UNESP-Botucatu, Brazil.

The Strongyloides venezuelensis which we used was originally obtained from wild rats ( $R$. norvegicus) at the beginning of the 1980s and has been kept in Wistar rats $(R$. norvegicus) at the Departamento de Parasitologia, UNESP, Botucatu.

Infective $S$. venezuelensis larvae in the $\mathrm{L}_{3}$ stage were produced by mixing feces from infected rats with sterilized equine feces, humidifying the mixture and incubating it in a Petri dish at $25{ }^{\circ} \mathrm{C}$ for three days. After incubation the $\mathrm{L}_{3}$ larvae were recovered by filtering and decanted into distilled water using a Baermann apparatus. The number of larvae in $10 \mu \mathrm{L}$ samples of the larval suspension were counted, using ten replicates, and the number adjusted to a suitable concentration for use in the experiments. We infected five-week to seven-week old mice by injecting them subcutaneously with $0.1 \mathrm{~mL}$ of the larval suspension containing 2000 S. venezuelensis larvae (Amarante and Oliveira-Sequeira, 2002).

\section{Parental and F1 susceptibility (experiment I)}

We mated seven NIH females and six C57BL/6 females with males of their own strains, resulting in 58 off- spring for the NIH strain and 48 for the $\mathrm{C} 57 \mathrm{BL} / 6$ strain. We also mated six NIH females with six C57BL/6 males to produce $33 \mathrm{~F} 1$ offspring and we also mated four C57BL/6 females with four NIH males to produce 40 offspring, the total F1 generation for this set of matings therefore being 73. The resistance was evaluated in groups of five males and five females randomly chosen from the offspring as follows: NIH pure-bred; C57BL/6 pure-bred; F1 hybrids from the NIH male x C57BL/6 female cross; and F1 hybrids from the $\mathrm{C} 57 \mathrm{BL} / 6$ male $\mathrm{x}$ NIH female cross. The mice were infected described above and then humanely sacrificed seven days later to determine the $S$. venezuelensis burden.

\section{F2 susceptibility (experiment II)}

In this experiment we mated three NIH females with three C57BL/6 males and four C57BL/6 females with four $\mathrm{NIH}$ males to produce $19 \mathrm{~F} 1$ siblings which were crossed to yield $400 \mathrm{~F} 2$ mice (210 males, 190 females). The five-week to seven-week old F2 animals were infected with $2000 \mathrm{~S}$. venezuelensis larvae and sacrificed as described. Tail samples of each animal were stored at $-80^{\circ} \mathrm{C}$ for subsequent DNA extraction.

\section{Worm burden determination}

It has been shown that the highest number of parthenogenetic S. venezuelensis females is detected seven days after infection (Oliveira-Sequeira and Amarante, 2001; Nakai and Amarante, 2001) and that more than $95 \%$ of the parasites in mice are located in the first $14 \mathrm{~cm}$ of the small intestine, which, on average, is less than one-third of the length of the small intestine (Nakai and Amarante, 2001). Based on these considerations, we sacrificed the mice seven days after infection and dissected out the initial third of the intestine from each mouse, sliced the excised intestine longitudinally and attached it to a wire support which we placed in a $20 \mathrm{~mL}$ tube in such a way as to prevent the intestine touching the bottom of the tube. Sufficient aqueous saline solution $(0.85 \% \mathrm{NaCl})$ was added to cover the intestine and the tubes incubated at $37^{\circ} \mathrm{C}$ for four hours, after which the intestines were shaken vigorously to completely release the nematodes and then formaldehyde solution $(38 \% \mathrm{w} / \mathrm{w}$ formalin) was added at a final concentration of $5 \%(\mathrm{v} / \mathrm{v})$ and the parasites counted using stereoscopic microscope.

\section{Statistical analysis}

The data from experiment I were analyzed using two classes (sex and group) and the PROC general linear model (GLM) of the SAS ${ }^{\circledR} 2001$ program version 8. In experiment II, the statistical analysis was similar, but the classes were sex and coat color. Means were compared by the minimum significant difference at the $5 \%$ of probability level. 
The statistical analysis was performed with transformed data $\left(\log _{10}\right)$ but, for clarity, the non-transformed arithmetic means $( \pm$ standard error, SE) or the data frequency are given in the results section.

\section{Results}

\section{Parental and F1 susceptibility (experiment I)}

The sex of the mice had no influence on the number of parasites recovered $(\mathrm{p}>0.05)$. The mean small intestine $S$. venezuelensis burden of the $\mathrm{F} 1$ mice from the NIH male $\mathrm{x}$ C57BL/ 6 female cross was $303.9 \pm 43.5$ while that of the C57BL/6 male $x$ NIH female cross was $229.0 \pm 34.8$, these values being not significantly different at $\mathrm{p}>0.05$.

Figure 1 shows the number of $S$. venezuelensis specimens recovered from the small intestines of the parental strains and the F1 crosses. The degree of resistance of the F1 mice was intermediate compared to that of the parental strains of the same age.

\section{F2 susceptibility (experiment II)}

As with experiment 1 , the sex of the mice did not influence parasite number. The mean small intestine $S$. venezuelensis burden for the 210 males was $539 \pm 26.6$ while that of the $190 \mathrm{~F} 2$ females was $513 \pm 24.8(\mathrm{p}>0.05)$.

The mean small intestine $S$. venezuelensis burden was $624 \pm 41.3$ for black $F 2$ mice $(n=72), 507 \pm 35.3$ for white $\mathrm{F} 2$ mice $(\mathrm{n}=104)$ and $504 \pm 24.6$ for gray F2 mice $(\mathrm{n}=224)$. Black F2 mice showed a significantly higher $(\mathrm{p}<0.05)$ parasite burden than white or gray mice.

Figure 2 shows the frequency distribution of $S$. venezuelensis recovered from the small intestines of infected F2 mice. The group of the $10 \%$ most resistant mice showed 21 to 97 parasites, while the group of the $10 \%$ most susceptible mice showed 1027 to 1433 parasites. The F2

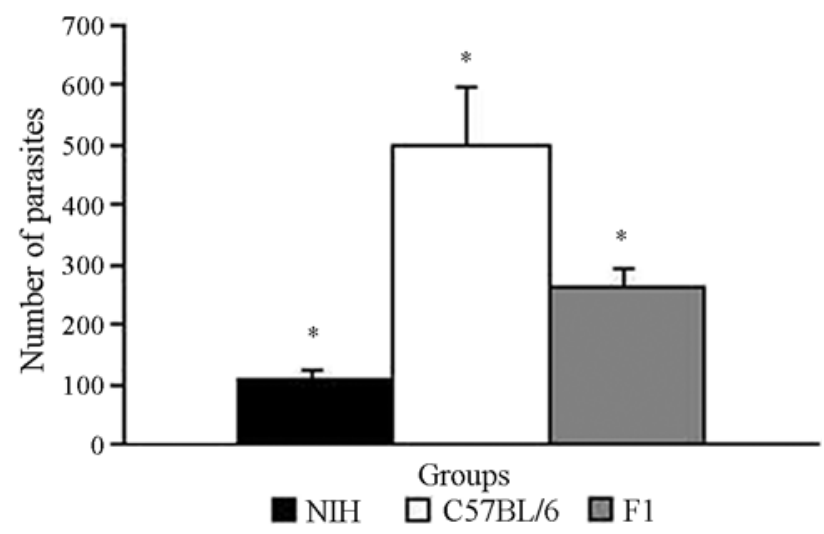

Figure 1 - Number of S. venezuelensis parthenogenetic females recovered from the first third of the small intestines of NIH, C57BL/6 and F1 mice infected with 2000 larvae. (*) Significantly different, $\mathrm{p}<0.05$ (PROC GLM- SAS $\odot, 2001$, version 8 ). Vertical bars indicate the standard error.

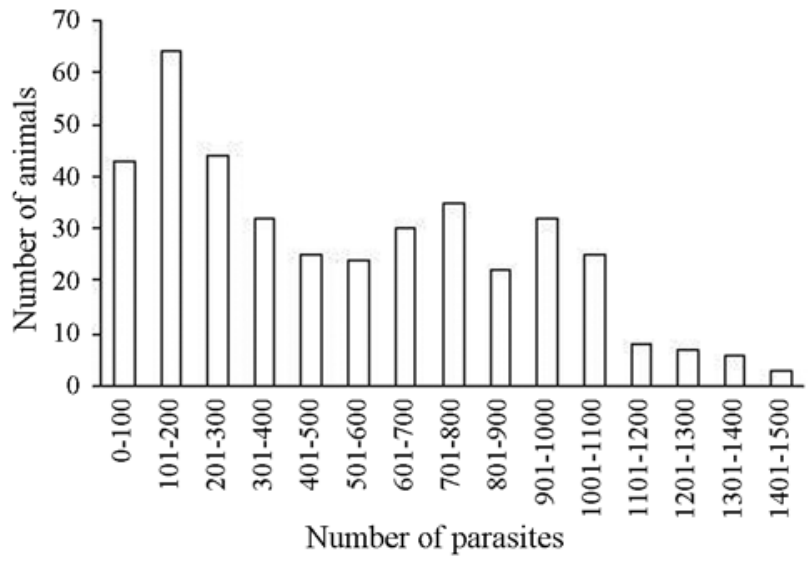

Figure 2 - Frequency distribution of the number of $S$. venezuelensis recovered from the small intestines of F2 mice seven days after infection with 2000 larvae.

mice used in this experiment were the descendants of seven $\mathrm{NIH}$ and C57BL/6 couples, but there was no influence of these couples on the susceptibility of the F2 animals $(\mathrm{p}>0.05)$.

\section{Discussion}

The NIH mice were more resistant to $S$. venezuelensis infection than the C57BL/6 mice, which agrees with the findings of Amarante and Oliveira-Sequeira (2002). The F1 mice showed an intermediate parasite burden in comparison to both the resistant (NIH) and susceptible (C57BL/6) parental strains. However, different results have been reported for NIH x CBA (susceptible) F1 mice infected with Trichuris muris (Wakelin 1975) and NIH x B10 (susceptible) F1 mice infected with Trichinella spiralis (Wakelin, 1980), for which the parasite burden in F1 animals was similar to that found in the resistant parental strain. According to Wakelin (1980), the low response of the susceptible strain to $T$. spiralis infection is inherited as a recessive trait. Behnke and Robinson (1985) demonstrated that F1 mice (NIH x C57BL/10 or NIH x B10G) showed a better response than the resistant NIH parental strain when infected by Nematospiroides dubius.

Amarante et al. (1999b) observed that adult F1 sheep from the cross between Florida Native (resistant) x Rambouillet (susceptible) were resistant to natural infections caused by gastrointestinal nematodes. However, lambs artificially infected with Haemonchus contortus were susceptible and showed similar performance to the susceptible breed (Amarante et al., 1999a). Together, these results suggest that there is a high level of heterosis which is favorable to gastrointestinal nematode resistance, although there are some exceptions as witnessed by the results published by Amarante et al. (1999a) and those shown in the present paper. 
It has been reported that the average number of the gastrointestinal nematode Heligmosomoides polygyrus in F2 mice was closer to that found in the resistant SWR strain than in the susceptible CBA strain (Iraqi et al., 2003). However, our experiments with $S$. venezuelensis showed high variability in the F2 mice, with many siblings being highly resistant while others were highly susceptible.

Nakanishi et al. (1989) demonstrated that testosterone reduced the response of lymphocytes, macrophages and eosinophils to primary infection of C57BL/6 mice by Brugia pahagi, consequently reducing resistance. Rivero et al. (2002) observed that, due to reduced plasma testosterone, castrated Wistar rats were less susceptible to $S$. venezuelensis primary infection in comparison to non-castrated rats and also found a significant increase in the susceptibility to $S$. venezuelensis in castrated Wistar females treated with testosterone. However, contrasting with these reports, our study indicated that the sex of the mice had no influence on the $S$. venezuelensis burden.

In our study, curiously, F2 mice with a black coat, which is the color of the susceptible parental strain (C57BL/6), were more susceptible than white or gray mice. Jordan and Beermann (2000) state that 90 loci are known to influence coat color in mice, and it is possible that genes determining coat color are located on the same chromosome as genes responsible for resistance or susceptibility to helminth infection.

It is important to point out that in our experiments with $S$. venezuelensis we investigated the resistance of the host under primary infection, because it has been reported that both the NIH and C57BL/6 strains showed strong immunity to secondary infections by $S$. venezuelensis (Amarante and Oliveira-Sequeira, 2002). In contrast, Iraqi et al. (2003) investigated the acquired resistance of mice after several infections with H. polygyrus and found seven QTLs related to acquired resistance on six chromosomes of F2 mice produced by crossing the resistant SWR strain with the susceptible CBA strain. The data and material obtained in our the present study will be used to identify QTLs associated to innate resistance to $S$. venezuelensis infection and may clarify the situation.

\section{Acknowledgments}

To the Brazilian agencies CAPES and CNPq for the grants to the first and second author, respectively.

\section{References}

Amarante AFT and Amarante MRV (2003) Breeding sheep for resistance to nematode infections. J Anim Vet Adv 2:147-161.

Amarante AFT, Barbosa MA, Oliveira MAG, Carmello MJ and Padovani CR (1992) Efeito da administração de oxfendazol, ivermectina e levamisol sobre os exames coproparasitoló- gicos de ovinos (Abstract in English). Braz J Vet Res Anim Sci 29:31-38.

Amarante AFT, Craig TM, Ramsey WS, Davis SK and Bazer FW (1999a) Nematode burdens and cellular responses in the abomasal mucosa and blood of Florida Native, Rambouillet and crossbred lambs. Vet Parasitol 80:311-324.

Amarante AFT, Craig TM, Ramsey WS, El-Sayed NME, Desouki AY and Bazer FW (1999b) Comparison of naturally acquired parasite burdens among Florida Native, Rambouillet and crossbred ewes. Vet Parasitol 85:61-69.

Amarante AFT and Oliveira-Siqueira TCG (2002) Strongyloides venezuelensis infection susceptibility of seven inbred strains of mice. Arq Bras Med Vet Zootec 54:273-278.

Amarante MRV, Yang PY, Kata SR, Lopes CR and Womack JE (2000) RH maps of bovine Chromosomes 15 and 29: Conservation of human chromosomes 11 and 5. Mamm Genome 11:364-368.

Band MR, Larson JH, Rebeiz M, Green CA, Heyen DW, Donovan J, Windish R, Steining C, Mahyuddin P, Womack JE and Lewin HA (2000) An ordered comparative map of the cattle and human genomes. Genome Res 10:1359-1368.

Behnke JM, Iraqi F, Menge D, Baker RL, Gibson J and Wakelin D (2003) Chasing the genes that control resistance to gastrointestinal nematodes. J Helminthol 77:99-109.

Behnke JM and Robinson M (1985) Genetic control of immunity to Nematospiroides dubius: A 9-day anthelmintic abbreviated immunizing regime which separates weak and strong responder strains of mice. Parasite Immunol 7:235-253.

Darvasi A (1998) Experimental strategies for the genetic dissection of complex traits in animal models. Nat Genet 18:19-24.

Echevarria F, Borba MFS, Pinheiro AC, Waller PJ and Hansen JW (1996) The prevalence of anthelmintic resistance in nematode parasites of sheep in southern Latin America: Brazil. Vet Parasitol 62:199-206.

Georges M (2001) Recent progress in livestock genomics and potential impact on breeding programs. Theriogenology 55:15-21.

Gogolin-Ewens KJ, Meeusen EN, Scott PC, Adams TE and Brandon MR (1990) Genetic selection for disease resistance and traits of economic importance in animal production. Rev Sci Tech 3:865-896.

Iannuzzi L, Gallagher DS, Di Meo GP, Schlapfer J, Perucatti A, Amarante MR, Incarnato D, Davis SK, Taylor JF and Womack JE (2001) Twelve loci from HSA10, HSA11 and HSA20 were comparatively FISH-mapped on river buffalo and sheep chromosomes. Cytogenet Cell Genet 93:124-126.

Iraqi FA, Behnke JM, Menge DM, Lowe A, Teale AJ, Gibson JP, Baker LR and Wakelin D (2003) Chromosomal regions controlling resistance to gastrointestinal nematode infections in mice. Mamm Genome 14:184-191.

Jordan S and Beermann F (2000) Nomenclature for identified pigmentation genes in the mouse. Pigment Cell Res 13:70-71.

Lyons LA, Laughlin TF, Copeland NG, Jenkins NA, Womack JE and O'Brien SJ (1997) Comparative anchor tagged sequences (CATS) for integrative mapping of mammalian genomes. Nat Genet 15:47-56.

Marshall JD, Mu JL, Cheah YC, Nesbitt MN, Frankel WN and Paigen B (1992) The AXB and BXA set of recombinant inbred mouse strains. Mamm Genome 3:669-680.

Menge DM, Behnke JM, Lowe A, Gibson JP, Iraqi FA, Baker RL and Wakelin D (2003) Mapping of chromosomal regions in- 
fluencing immunological responses to gastrointestinal nematode infections in mice. Parasite Immunol 25:341-349.

Modi WS, Amarante MR, Hanson M, Womack JE and Chidambaram A (1998) Assignment of the mouse and cow CXC chemokine genes. Cytogenet Cell Genet 81:213-216.

Nakai ES and Amarante AFT (2001) Infecção experimental de camundongos (Mus musculus) e ratos (Rattus norvegicus) com Strongyloides venezuelensis (Abstract in English). Rev Bras Parasitol Vet 10:1-6.

Nakanishi H, Horii Y, Terashima K and Fujita K (1989) Effect of testosterone on the susceptibility of C57BL/6 mice to infection with Brugia pahangi with reference to inflammatory cell response. J Parasitol 75:455-460.

Negrão-Corrêa D, Souza DG, Pinho V, Barsante MM, Souza ALS and Teixeira MM (2004) Platelet-activating factor receptor deficiency delays elimination of adult worms but reduces fecundity in Strongyloides venezuelensis-infected mice. Infect Immun 72:1135-1142.

O'Brien SJ, Menotti-Raymond M, Murphy WJ, Nash WG, Wienberg J, Stanyon R, Copeland NG, Jenkins NA, Womack JE and Marshall Graves JA (1999) The promise of comparative genomics in mammals. Science 286:458-481.

Oliveira-Sequeira TCG and Amarante AFT (2001) Dynamics of Strongyloides venezuelensis infection and relationship between fecal egg counts and parasite burden in Swiss mice. Rev Bras Med Vet 23:99-102.
Rexroad CE, Bennett GL, Stone RT, Keele JW, Fahrenkrug SC, Freking BA, Kappes SM and Smith TP (2001) Comparative mapping of BTA15 and HSA11 including a region containing a QTL for meat tenderness. Mamm Genome 12:561565.

Rivero JC, Inoue Y, Murakami N and Horii Y (2002) Androgenand estrogen-dependent sex differences in host resistance to Strongyloides venezuelensis infection in Wistar rats. J Vet Med Sci 64:457-461.

Sasaki Y, Yoshimoto T, Maruyama H, Tegoshi T, Ohta N, Arizono N and Nakanishi K (2005) IL-18 with IL-2 protects against Strongyloides venezuelensis infection by activating mucosal mast cell-dependent type 2 innate immunity. J Exp Med. 202:607-616.

Valladares-Hernandez M, Naessens J, Gibson JP, Musoke J, Nagda S, Rihet P, ole-MoiYoi OK and Iraqi FA (2004) Confirmation and dissection of QTL controlling resistance to malaria in mice. Mamm Genome 15:390-398.

Wakelin D (1975) Genetic control of immune responses to parasites: Immunity to Trichuris muris in inbred and randombred strains of mice. Parasitology 71:51-60.

Wakelin D (1980) Genetic control of immunity to parasites. Infection with Trichinella spiralis in inbred and congenic mice showing rapid and slow responses to infection. Parasite Immunol 2:85-98.

Waller PJ (1997) Anthelmintic resistance. Vet Parasitol 72:391412.

Associate Editor: André Luis Paranhos Perondini 